\title{
Priority Determination of Application Candidate Using Ward and Peppard's Composite Matrix Portfolio and Business Process Analysis for Customer Relationship Management (CRM)
}

\author{
Astria Hijriani' ${ }^{1)}$ Aprillia Dewi ${ }^{2}$ \\ ${ }^{1,2)}$ Computer Science Department, Faculty of Math and Science, University of Lampung, Soemantri \\ Brodjonegoro Street Number 01 Gedung Meneng, Bandar Lampung, Lampung Indonesia \\ e-mail: astria.hijriani@,fmipa.unila.ac.id ${ }^{1)}$, aprilliadewi06@gmail.com ${ }^{2)}$
}

\begin{abstract}
Abstrak
Dengan menggunakan CRM, organisasi akan dapat mengidentifikasi kebutuhan dan kebutuhan pelanggan, sehingga akan meningkatkan layanan. Perancangan CRM di Departemen Ilmu Komputer menggunakan Zachman Framework adalah salah satu upaya pelayanan kepada pelanggan yang lebih baik. Zachman Framework belum menyediakan metode untuk menentukan prioritas calon aplikasi yang akan dirancang. Dalam penelitian ini penulis menggunakan portofolio matriks komposit Ward dan Peppard dan analisis proses bisnis untuk prioritas untuk menentukan prioritas calon aplikasi. Fase penentuan kandidat dengan menggunakan matriks komposit dan proses bisnis Ward dan Peppard terdiri atas enam tahapan. Hasilnya berupa pemetaan untuk masing-masing kandidat aplikasi/ sistem aplikasi ke dalam empat kuadran yang disediakan dalam matriks komposit untuk proses pengambilan keputusan. Matriks terdiri dari kunci operasional, strategis, potensi tinggi dan dukungan. Pemetaan matriks komposit Ward dan Peppard kemudian digunakan untuk memisahkan kandidat aplikasi menjadi dua kelompok, prioritas utama dari kelompok aplikasi / sistem informasi dan prioritas non-utama dari kelompok aplikasi/sistem informasi. Ada lima sistem informasi yang diklasifikasikan ke dalam kelompok aplikasi/ sistem informasi prioritas utama yang direkomendasikan untuk dikembangkan pada penelitian selanjutnya.
\end{abstract}

Kata Kunci: Ward and Peppard, CRM, Universitas, analisis proses bisnis

Abstract

By using CRM, the organization will be able to identify of what customer requires and needs, thus will improve the service. The designing of CRM the Computer Science Department using Zachman Framework is one of the approach methods to serve customers in better ways. Zachman Framework has not provided a method for determining the priority of the application candidates that will be designed. In this research the authors use the Ward and Peppard's composite matrix portfolio and business process analysis for priority to determine the priority of application candidates. The phase of candidate's determination by using Ward and Peppard's composite matrix and business process consist of six steps. The results are in the form of mapping for each application candidatelapplication system into four quadrants which are provided in composite matrix for the decision-making process. The matrix consists of key operational, strategic, high potential and support. The mapping on Ward and Peppard's composite matrix is then used to separate the application candidates into two groups, the main priority of application group/information system and non-main priority of application group/information system. There are five information systems which are classified into main priority application group/information system and recommended to be developed in further research.

Keywords: Ward and Peppard, CRM, University,process business analysis 


\section{INTRODUCTION}

An organization or corporate always develops the technology that used to support all activities. However, the information system which is often developed not suitable for the needs. One of the critical aspects of an organization or corporate is the customer. Customer Relationship Management (CRM) is one of the business strategies that prioritize the relationship with the customer [1]. According to Kotler and Keller, CRM enables the corporate to manage the detailed information about each customer and maximize the service [2].

One of the CRM applications is in the college [3], some previous researches have discussed the implementation of the Zachman Framework in college [4-5] and the use of CRM with Zachman Framework in college [6-7]. The use of information technology is useful to achieve the CRM so that it can run well [8].

Computer Science Department of University of Lampung has developed information systems, but it has not implemented CRM, to perform the CRM design, an application candidate analysis is required, before it is designed using Zachman Framework on further phases.

The determination of the priority of application candidate in this research is using the Ward and Peppard's Composite Matrix Portfolio and Process Business Analysis. Ward and Peppard's Composite Matrix portfolio is one of methods to establish the application portfolio so that it can be identified for what kinds of the role or contribution of each existing application candidate toward that corporate, before determining the application candidate that will be designed, a business process analysis is conducted at the Computer Science Department.

Ward and Peppard describe each element in Composite Matrix portfolio as follow.

1. Strategic, indicates that applications are in a critical position toward the success of the business organization.

2. Key Operational, indicates that the built-application to support the business operations and to help avoid any weaknesses. This in-quadrant application is the application that should be owned by every organization to be able to survive in business competition.
3. Support, indicates that the application can improve the management efficiency and, but it is not a must-have application.

4. High Potential, indicates that application may be able to create new business opportunities in the future, but it has not been proven yet.

In general, Composite Matrix portfolio will help the organization to analyze the running application or the pre-existing application which will be planned or will be built into the four quadrants, so that the organization will be able to identify the level of application importance in the organization [9].

\section{RESEARCH METHODS}

The Research phases to obtain the application priority using Ward and Peppard's Composite Matrix portfolio are as follow, shown in Figure 1.

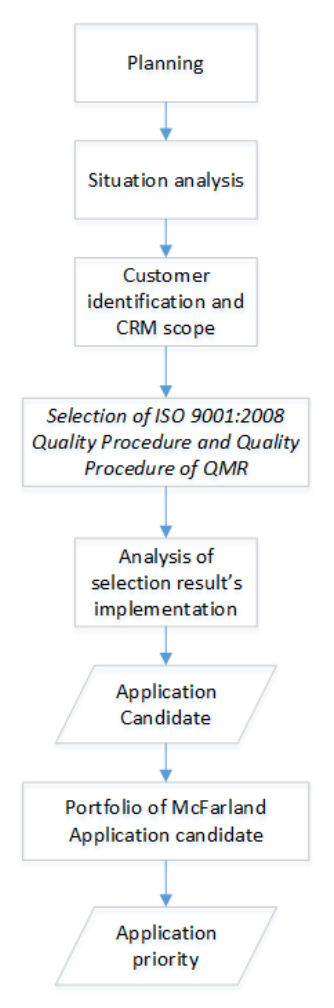

Figure 1. Research flow

The research phases that will be conducted are as follows.

Priority Determination of Application Candidate Using Ward and Peppard's Composite Matrix Portfolio and Business Process Analysis for Customer Relationship Management (CRM) (Astria

Hijriani) 


\section{A. Planning}

The planning phase in the form of determining the research location and research scope.

\section{B. Situation Analysis}

The situation analysis includes the identification of organizational key information, SWOT analysis and value chain analysis based on the business process chart in the Computer Science Department [10].

C. Customers Identification in the Computer Science Department and Scope of CRM process

The researchers identify the individuals who become the customer in the Computer Science Department by interviewing the head of the Computer Science Department and determining the scope of CRM that will be discussed.

D. Selection of ISO 9001:2008 Quality Procedure and Quality Procedure of Quality Management Representative (QMR)

After knowing the kinds of business processes which are available in Computer Science Department via value chain analysis, the researchers then classify 78 existing quality procedures according to the scope of the business process and conduct the selection toward the ISO 9001:2008 quality procedure and quality procedure of quality management representative which is related to the customer.

\section{E. Analysis of Each Quality Procedure implementation}

Each quality procedure as the result of the previous process becomes the input for implementation analysis. In the implementation analysis, it will be seen of how that implementation process runs in current time, and then which problems occur with the process that time, also the activity which is required to be conducted to improve the condition.

\section{F. Application Candidate}

The result of implementation analysis is in the form of application candidate/ information system which is originated from the case solution that can be solved with the information system.

\section{G. Ward and Peppard's Composite Matrix Portfolio}

That application candidate is then mapped in four quadrants using Ward and Peppard's Composite matrix portfolio.

\section{H. Application Priority}

The next phase is grouping the application into two categories namely the main priority application and not main priority application based on the results of the mapping of Ward and Peppard's Composite matrix portfolio.

\section{RESULTS AND DISCUSSIONS}

\section{A. Planning}

The research is conducted in the Computer Science Department of University of Lampung. The researchers do a literature study about CRM, Ward and Peppard's Composite Matrix portfolio and Zachman Framework.

B. Situation Analysis

1) Information Identification related to Computer Science Department:

a) The vision of the Computer Science Department.

b) The mission of the Computer Science Department.

c) The objectives statements of the Computer Science Department.

d) The target formulations of the Computer Science Department which are relevant to the vision and mission of the Computer Science Department.

e) The organizational structure.

2) SWOT analysis: To know the strengths, weaknesses, opportunities and threat that 
exist in Computer Science Department so that it can help Computer Science Department to formulate solutions to become better in future especially related to the customer service.

3) Value Chain Analysis: Value chain analysis is the method to know of which item that is included in the main business processes and supporting business processes in the Computer Science Department. Business Process chart of the Computer Science Department can be seen in Figure 2

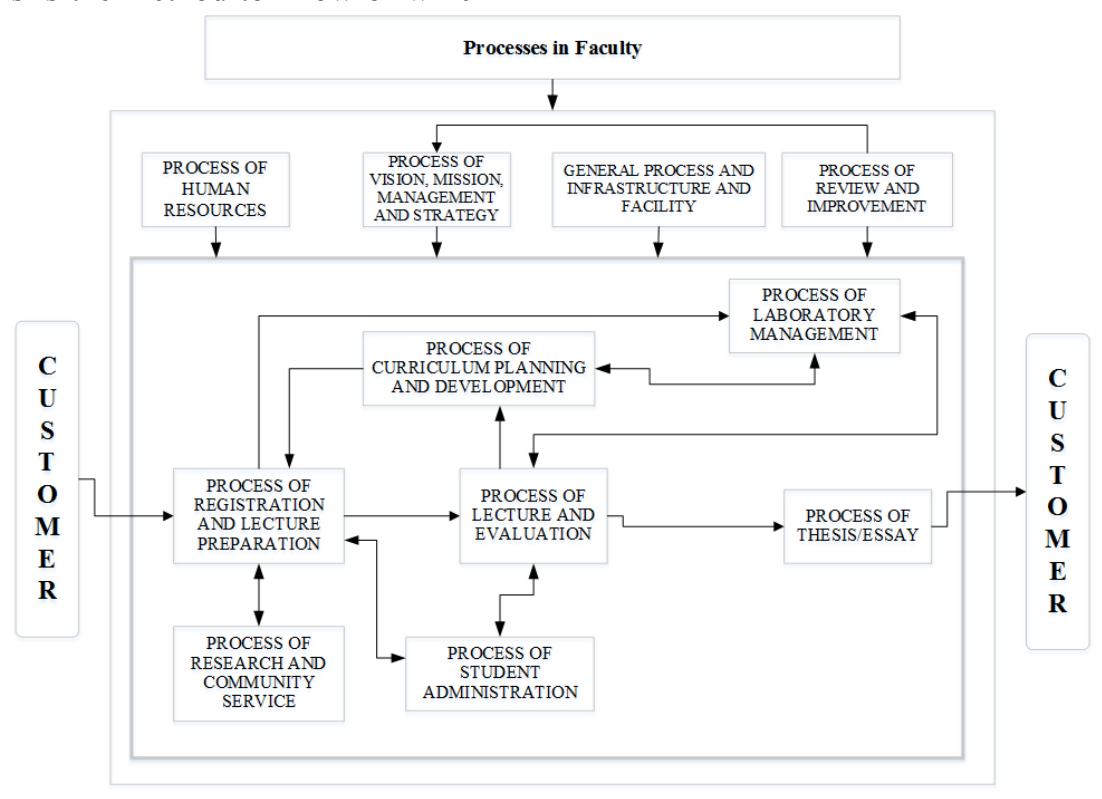

Figure 2. Business Process chart of Computer Science Department

Based on the business process chart in Figure 2, the business process in the Computer Science
Department is grouped five core value chain according to the standard as shown in Figure 3.

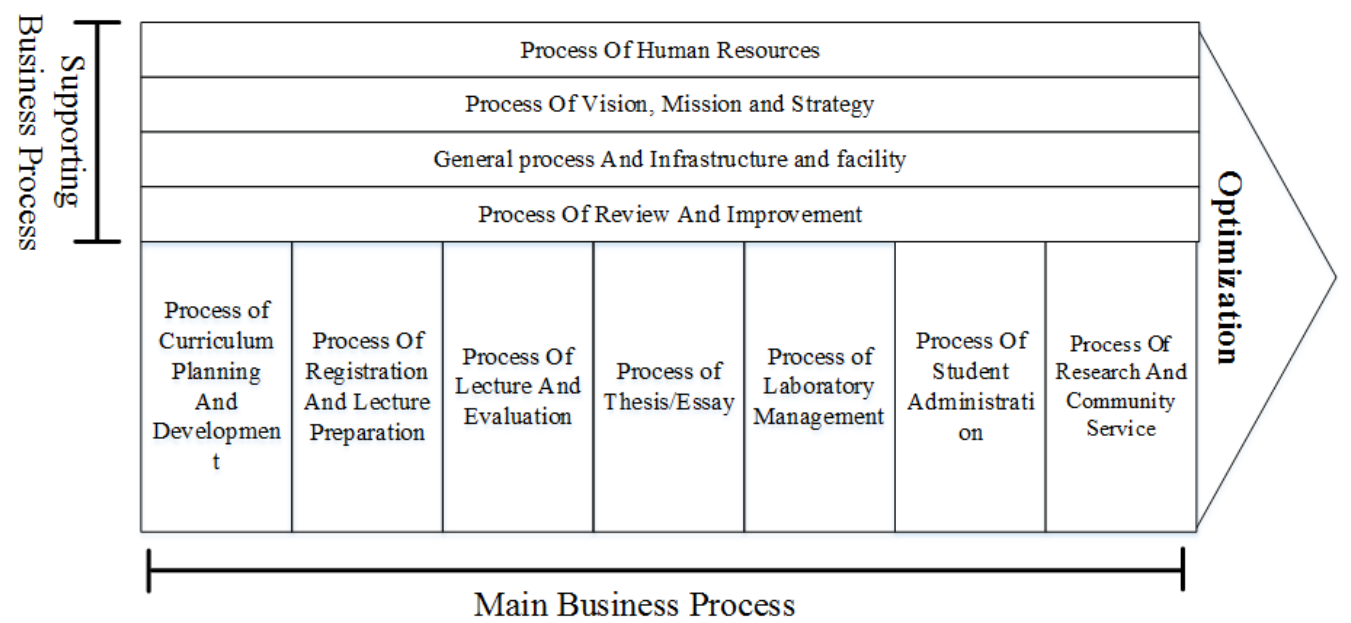

Figure 3. Business process in Computer Science Department grouped to five core value chain 


\section{Customer Identification and scope of CRM}

The customers from the Computer Science Department are students, graduates and external agencies/corporates of where graduates work. The range of CRM to be discussed includes two timings that are during the core process of lectures and post lecture process which is for the graduates of the Computer Science Department.

D. Business Process Analysis and selection of ISO 9001:2008 Quality Procedures and Quality Procedure of Quality Management Representative

ISO9001 certification body has certified computer Science Department since 2014. All academic, employee affairs, student affairs processes, facilities and infrastructures have been administrated by 78 Quality Procedures ISO 9001:2008 and eight quality procedures of Quality Management Representative. It is obtained for 27 quality procedures related to a customer of the Computer Science Department which can be seen in Table 1.

Table 1. List of Quality Procedures related to customer

\begin{tabular}{|c|c|c|}
\hline No & $\begin{array}{l}\text { Number of } \\
\text { Quality } \\
\text { Procedures }\end{array}$ & Quality Procedure \\
\hline 1. & 35 & Implementation of academic guidance \\
\hline 2. & 40 & $\begin{array}{l}\text { Implementation of Department practice } \\
\text { and service }\end{array}$ \\
\hline 3. & 15 & $\begin{array}{l}\text { Implementation, monitoring and } \\
\text { evaluation process of learning }\end{array}$ \\
\hline 4. & 24 & $\begin{array}{l}\text { Implementation of practice } \\
\text { examination for bachelor and Diploma } \\
\text { Program }\end{array}$ \\
\hline 5. & 23 & $\begin{array}{l}\text { Implementation midterm exam/final } \\
\text { exam for bachelor and diploma } \\
\text { Program }\end{array}$ \\
\hline 6. & 14 & $\begin{array}{l}\text { Implementation Internship } \\
\text { Professional Placement }\end{array}$ \\
\hline 7. & 26 & $\begin{array}{l}\text { Internship / Professional Placement } \\
\text { seminars }\end{array}$ \\
\hline 8. & 16 & Implementation of a short semester \\
\hline 9. & 31 & Submission of guided lecture \\
\hline 10. & 13 & $\begin{array}{l}\text { Appointment of advisor/examiner and } \\
\text { execution of thesis guidance }\end{array}$ \\
\hline 11. & 32 & $\begin{array}{l}\text { Handling of research permit for } \\
\text { bachelor and diploma students }\end{array}$ \\
\hline 12. & 08 & $\begin{array}{l}\text { Proposal seminar and final seminar for } \\
\text { bachelor student }\end{array}$ \\
\hline 13. & 25 & Execution of thesis examination \\
\hline 14. & 27 & Thesis Seminar \\
\hline 15. & 45 & Free from any laboratory matters \\
\hline 16. & 41 & Laboratory equipment lending permit \\
\hline
\end{tabular}

\begin{tabular}{|c|c|c|}
\hline No & $\begin{array}{l}\text { Number of } \\
\text { Quality } \\
\text { Procedures }\end{array}$ & Quality Procedure \\
\hline & & $\begin{array}{l}\text { by internal and external students of } \\
\text { Unila }\end{array}$ \\
\hline 17. & 42 & $\begin{array}{l}\text { Laboratory service from an external } \\
\text { member of the Computer Science } \\
\text { Department }\end{array}$ \\
\hline 18. & 38 & $\begin{array}{l}\text { Management of department reading } \\
\text { room }\end{array}$ \\
\hline 19. & 66 & Interview of Dean of Department \\
\hline 20. & 61 & $\begin{array}{l}\text { Facilities and infrastructures lending } \\
\text { permit for lecture process }\end{array}$ \\
\hline 21. & 72 & $\begin{array}{l}\text { The lending of facilities and } \\
\text { infrastructures }\end{array}$ \\
\hline 22. & 74 & $\begin{array}{l}\text { Implementation service and activity } \\
\text { report of PKM DIKTI }\end{array}$ \\
\hline 23. & 78 & $\begin{array}{l}\text { The service of submission of PKM } \\
\text { DIKTI Proposal }\end{array}$ \\
\hline 24. & 77 & $\begin{array}{l}\text { Evaluation of graduate performance by } \\
\text { stakeholder }\end{array}$ \\
\hline 25. & 03 (QMR) & Handling of complaints \\
\hline 26. & 04 (QMR) & Measurement of customer satisfaction \\
\hline 27. & 05 (QMR) & Satisfaction of Lecture process \\
\hline
\end{tabular}

\section{E. Analysis of Quality Procedure Implementation}

From the 27 quality procedures that are selected from the previous phase, further, it is analyzed one by one which is associated with the current implementation, the constraints that occur with the present application and possible activities to improve the use of the quality procedure.

\section{F. Application Candidates}

After analyzing the implementation, the obtained solutions are then separated between problems that can be solved with the information system and problems that cannot be solved by the information system. Solutions from the problems that can be solved by information system then produce 14 application candidates. Those information systems are:

1. Information System of Room or Laboratory lending and practice attendance (new);

2. Information System of Lecturing Files (new);

3. Information System of Professional Placement/Internship (update);

4. Support System of Appointment of Advisor/Examiner (new);

5. Monitoring Information System of Thesis for Bachelor degree (update);

6. Information System of Thesis for Diploma (update);

7. Information System of Management of reading room (new);

8. Information System of Book Donation (update); 
9. Information System of free from laboratory matters (new);

10. Information System of Lending facilities and infrastructures(update);

11. PKM Application (web and android) (new);

12. Information System of Tracer Study (update);

13. Information System of ISO service Questionnaire (update);

14. Information System odf students and lecture Database (update).

G. Portfolio of Ward and Peppard's Composite Matrix

After obtaining 14 application candidates/information systems from the analysis of quality procedure related to the customer, then the researchers conduct a mapping of information systems into the quadrants of Ward and Peppard' Composite Matrix. The mapping on each information systems into four quadrants of Ward and Peppard's Composite Matrix requires questionnaires. In this research, six individuals become the respondents, they are the head of the Computer Science Department for several periods. In table 2 and 3, we can check the questions delivered by each respondent.

Table 2. Guide of general questions for the determination of Composite Matrix Portfolio

(Ward \& Peppard, 2002).

\begin{tabular}{cl}
\hline Items & \multicolumn{1}{c}{ General Questions } \\
\hline $\mathrm{A}$ & $\begin{array}{l}\text { Are the results visible for the business } \\
\text { profit competitiveness? }\end{array}$ \\
\hline $\mathrm{B}$ & $\begin{array}{l}\text { Is it possible to achieve a specific business } \\
\text { goal and/or critical success factors? }\end{array}$ \\
\hline $\mathrm{C}$ & $\begin{array}{l}\text { Can it solve the business constrains } \\
\text { related to the competition? }\end{array}$ \\
\hline $\mathrm{D}$ & $\begin{array}{l}\text { Avoiding business risk in the future so } \\
\text { that it will not arise in the short time? }\end{array}$ \\
\hline $\mathrm{E}$ & $\begin{array}{l}\text { Iincrease business productivity and } \\
\text { reduce the costs? }\end{array}$ \\
\hline $\mathrm{F}$ & $\begin{array}{l}\text { Is it possible for the department to meet } \\
\text { the needs? }\end{array}$ \\
$\mathrm{G}$ & $\begin{array}{l}\text { Make it possible for the unseen profit } \\
\text { today but it could probably have resulted } \\
\text { in point (a) or (b) above? }\end{array}$ \\
\hline
\end{tabular}

Table 3. Guide of general questions for determination Composite Matrix Portfolio (Ward \& Peppard, 2002).

\begin{tabular}{cl}
\hline Items & \multicolumn{1}{c}{ Specific Questions } \\
\hline I & $\begin{array}{l}\text { If it is implemented, what is the profit of } \\
\text { the business and has the way to achieve } \\
\text { been visible? }\end{array}$ \\
\hline Ii & $\begin{array}{l}\text { If it is failed to meet the goal, is it risking } \\
\text { the business and can it be identified? }\end{array}$ \\
\hline
\end{tabular}

Steps to answer the questionnaire are as follows.

1) Answer the question based on the observation on the current condition of Department and projection of the department in the future.

2) Select one of the most relevant answers with the information system from the seven questions which are delivered on each information system by marking it with checklist sign $(\sqrt{ })$.

3) If the answer in the item " $A$ " or " $B$ " is "Yes" (general question), then answer the question in item 1 (specific question).

4) If the answer in item " $F$ " is "Yes" (general question), then answer the question in item 2 (specific question).

After obtaining the answers from each respondent, then the results of the questionnaire are recapitulated and interpreted. Table 4 is the result of the recapitulation of the survey, the letter " $Y$ " refers to the maximum number of checklists for each information system.

Table 4. The result of questionnaire recapitulation

\begin{tabular}{|c|c|c|c|c|c|c|c|c|}
\hline \multirow[b]{2}{*}{ No } & \multirow{2}{*}{$\begin{array}{c}\text { Information } \\
\text { System }\end{array}$} & \multicolumn{7}{|c|}{ Answer "Y" } \\
\hline & & $\mathbf{A}$ & $\mathbf{B}$ & $\mathrm{C}$ & $\mathbf{D}$ & $\mathbf{E}$ & $\mathbf{F}$ & $\mathbf{G}$ \\
\hline 1. & $\begin{array}{l}\text { Information System } \\
\text { of Room or } \\
\text { Laboratory lending } \\
\text { and practice } \\
\text { attendance (new) }\end{array}$ & & $\mathrm{Y}$ & & $\bar{Y}$ & & & \\
\hline 2. & $\begin{array}{l}\text { Information System } \\
\text { of Lecturing Files } \\
\text { (new) }\end{array}$ & & $\mathrm{Y}$ & & & & $\mathrm{Y}$ & \\
\hline 3. & $\begin{array}{l}\text { Information System } \\
\text { of Professional } \\
\text { Placement/Internship } \\
\text { (update) }\end{array}$ & $\mathrm{Y}$ & $\mathrm{Y}$ & & & & & \\
\hline 4. & $\begin{array}{l}\text { Support System of } \\
\text { Appointment for } \\
\text { Advisor/Examiner } \\
\text { (new) }\end{array}$ & & & & & $\mathrm{Y}$ & & \\
\hline 5. & $\begin{array}{l}\text { Information System } \\
\text { of Monitoring of } \\
\text { Thesis for bachelor } \\
\text { degree (update) }\end{array}$ & & $\mathrm{Y}$ & & & & & \\
\hline 6. & $\begin{array}{l}\text { Information System } \\
\text { of Thesis for } \\
\text { Diploma (update) }\end{array}$ & & $\mathrm{Y}$ & & $\mathrm{Y}$ & & & \\
\hline 7. & $\begin{array}{l}\text { Information System } \\
\text { of Management of } \\
\text { reading room (new) }\end{array}$ & & & & & $\mathrm{Y}$ & & \\
\hline 8. & $\begin{array}{l}\text { Information System } \\
\text { of Book Donation } \\
\text { (update) }\end{array}$ & & & & & & & \\
\hline
\end{tabular}


SYSTEMIC

Vol. 1, No. 1, Agustus 2018, 14-19

\begin{tabular}{|c|c|c|c|c|c|c|c|c|}
\hline \multirow[b]{2}{*}{ No } & \multirow{2}{*}{$\begin{array}{c}\text { Information } \\
\text { System }\end{array}$} & \multicolumn{7}{|c|}{ Answer "Y" } \\
\hline & & $\mathbf{A}$ & $\mathbf{B}$ & $\mathrm{C}$ & D & $\mathbf{E}$ & $\mathbf{F}$ & $\mathbf{G}$ \\
\hline 9. & $\begin{array}{lr}\begin{array}{l}\text { Information } \\
\text { of free }\end{array} & \begin{array}{r}\text { System } \\
\text { from }\end{array} \\
\text { laboratory } & \text { matters } \\
\text { (new) } & \end{array}$ & & & $\mathrm{Y}$ & & & & $\mathrm{Y}$ \\
\hline 10. & $\begin{array}{l}\text { Information System } \\
\text { of Lending facilities } \\
\text { and infrastructures } \\
\text { (update) }\end{array}$ & & & & $\mathrm{Y}$ & & $\mathrm{Y}$ & \\
\hline 11. & $\begin{array}{l}\text { PKM Application } \\
\text { (web and android) } \\
\text { (new) }\end{array}$ & & & & & & & $\mathrm{Y}$ \\
\hline 12. & $\begin{array}{lr}\text { Information } & \text { System } \\
\text { of Tracer } & \text { Study } \\
\text { (update) } & \\
\end{array}$ & & $\mathrm{Y}$ & & & & & \\
\hline 13. & $\begin{array}{l}\text { Information } \text { System } \\
\text { of ISO service } \\
\text { Questionnaire } \\
\text { (update) }\end{array}$ & $\mathrm{Y}$ & & & & $\mathrm{Y}$ & & \\
\hline 14. & $\begin{array}{l}\text { Information System } \\
\text { of students and } \\
\text { lecture Database } \\
\text { (update) }\end{array}$ & & & & & & $\mathrm{Y}$ & \\
\hline
\end{tabular}

for each information system which is divided into four quadrants appropriate to the level of priority in the Computer Science Department.

Table 6. The mapping of application candidates in Ward Peppard's Composite Matrix

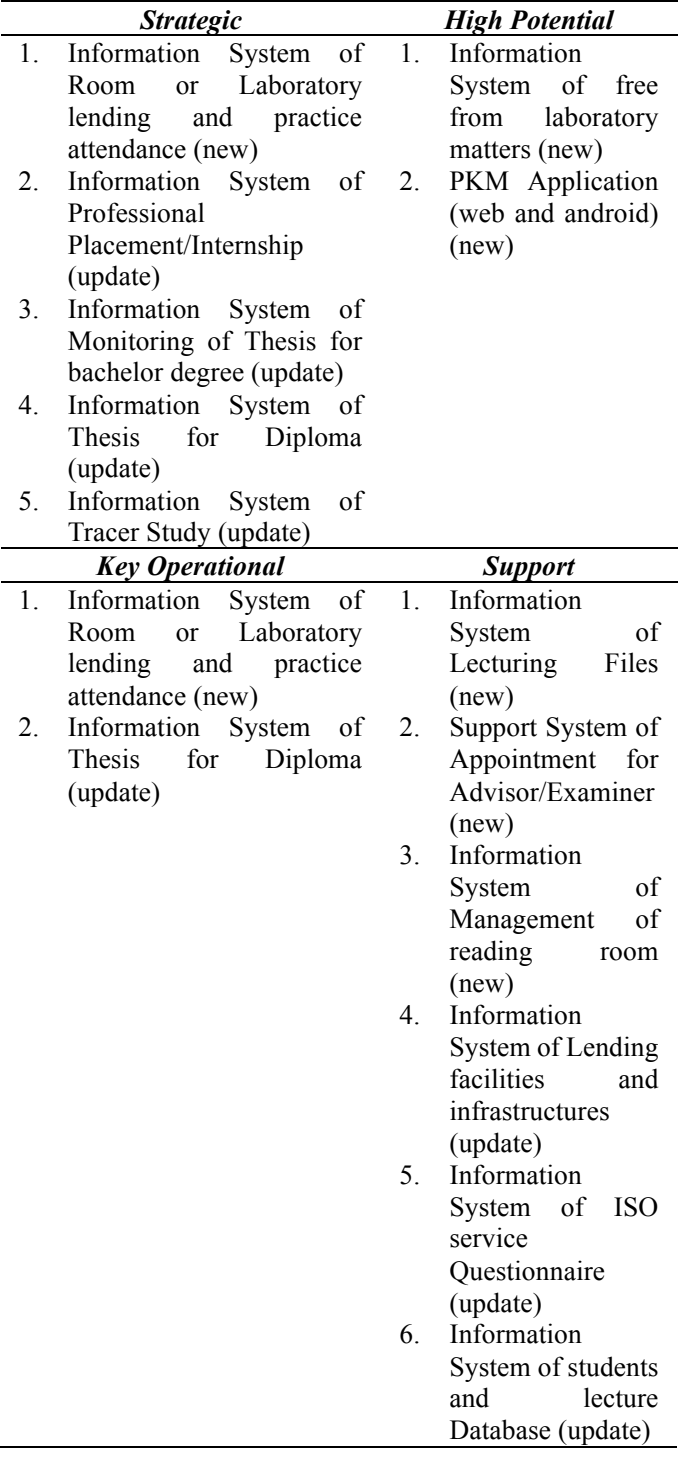

\section{H. Application Priority}

From the result of mapping with Ward Peppard's Composite Matrix, the existing 14 application candidates/information system are grouped into two categories, they are the main priority application category and non-main priority application category. The main priority applications are the applications which, in table 6, are included in the strategic quadrant or key operational quadrant or both. Meanwhile the 
applications which are grouped in the support quadrant or high potential quadrant or both are incorporated into the non-main priority application category. In table 7, we can see the classification of those applications/information systems.

Table 7. Application Grouping according to its priority

\begin{tabular}{|c|c|}
\hline Main priority & Non-main Priority \\
\hline $\begin{array}{l}\text { 1. Information System of } \\
\text { Room or Laboratory } \\
\text { lending and practice } \\
\text { attendance (new) }\end{array}$ & $\begin{array}{l}\text { 1. } \begin{array}{l}\text { Information } \\
\text { of fystem } \\
\text { laboratory } \\
\text { (new) }\end{array} \\
\text { matters }\end{array}$ \\
\hline $\begin{array}{l}\text { 2. Information System of } \\
\text { Professional Placement } \\
\text { /Internsgip (update) }\end{array}$ & $\begin{array}{l}\text { 2. PKM Application } \\
\text { (web and android) } \\
\text { (new) }\end{array}$ \\
\hline $\begin{array}{l}\text { 3. Information System of } \\
\text { Monitoring of Thesis for } \\
\text { Bachelor degree }\end{array}$ & $\begin{array}{l}\text { 3. Information System } \\
\text { of Lecturing Files } \\
\text { (new) }\end{array}$ \\
\hline $\begin{array}{l}\text { (update) } \\
\text { 4. Information System of } \\
\text { Thesis for Diploma } \\
\text { (update) }\end{array}$ & $\begin{array}{l}\text { 4. Support System of } \\
\text { Appointment for } \\
\text { Advisor/Examiner } \\
\text { (new) }\end{array}$ \\
\hline $\begin{array}{l}\text { 5. Information System of } \\
\text { Tracer Study (update) }\end{array}$ & $\begin{array}{l}\text { 5. Information System } \\
\text { of Management of } \\
\text { reading room (new) }\end{array}$ \\
\hline & $\begin{array}{l}\text { 6. Information System } \\
\text { of Lending the } \\
\text { facilities } \\
\text { infrastructures } \\
\text { (update) }\end{array}$ \\
\hline & $\begin{array}{l}\text { 7. Information System } \\
\text { of ISO service } \\
\text { Questionnaire } \\
\text { (update) }\end{array}$ \\
\hline & $\begin{array}{l}\text { 8. Information System } \\
\text { of students and } \\
\text { lecture Database } \\
\text { (update) }\end{array}$ \\
\hline & $\begin{array}{l}\text { 9. Information system } \\
\text { for Book Donation } \\
\text { (update) }\end{array}$ \\
\hline
\end{tabular}

\section{CONCLUSIONS}

From the discussion in the previous chapter, it can be concluded.

A. This research has defined the customer scope in the Computer Science Department, they are the students, graduates and external agencies/corporates.

B. Ward and Peppard's Composite Matrix Portfolio and business process analysis help to map the application candidates into four quadrants according to the contribution of each application for the Computer Science Department.
C. It produces 14 application candidates related to the CRM in the Computer Science Department.

D. There are 5 applications included in main priority category, they are Information System of Room or Laboratory lending and practice attendance (new), Information System of Professional Placement/Internship (update), Information System of Monitoring of Thesis for bachelor degree (update), Information System of Thesis for Diploma (update), Information System of Tracer Study (update).

\section{FUTURE WORKS}

Some matters that have not been discussed in this research are the definition of each cell in Zachman Framework related to the information systems which are included in the main priority application and non-main priority application category.

\section{REFERENCES}

[1] Buttle, F., Customer Relationship Management (Manajemen Hubungan Pelanggan) translate by Arif Subiyanto. Malang: Bayu Media Publishing, 2007.

[2] Kotler, P., \& Keller, K. L., Marketing Management (Manajemen Pemasaran) translate by Benyamin Molan. Jakarta: Indeks, 2008.

[3] Syaekhoni, M. A., Mulyanto, A., \& 'Uyun, S., Sistem Informasi Akademik dengan Konsep Collaborative Customer Relationship Management. Seminar Nasional VI SDM Teknologi Nuklir (hal. 385-393). Yogyakarta: STTN-BATAN dan Fakultas Saintek UIN Sunan Kalijaga, 2010.

[4] Kurniawan, B., Enterprise Architecture Planning Sistem Informasi pada Perguruan Tinggi Swasta dengan Zachman Framework. Majalah Ilmiah UNIKOM, 9(1), 21-31, 2011.

[5] Slameto, A. A., Utami, E., \& Pangera, A. A., Penerapan Zachman Framework Dalam Merancang SIstem Pelaporan Kerusakan Komputer. Jurnal Telematika, 5(2), 2012. 
SYSTEMIC

Vol. 1, No. 1, Agustus 2018, 14-19

[6] Deriani, N. W., Analisa Perancangan Model Customer Relationship Management pada STMIK STIKOM Bali. Jurnal VOI STMIK Tasikmalaya, 5(2), 43-55, 2015.

[7] Wahyu, F., Budiyanto, D., \& Rahayu, F. S., Penerapan Zachman Framework dalam Merancang Arsitektur Sistem Informasi (Studi Kasus UPN "Veteran" Jawa Timur). SCAN, 10(3), 31-38, 2015

[8] Kundre, J. A., Wisnubadhra, I., \& Suselo, T., Penerapan Customer Relationship Management dengan Dukungan Teknologi Informasi pada PO. Chelsy . Seminar Nasional Teknologi Informasi dan Multimedia 2013. Yogyakarta: STMIK AMIKOM, 2013.

[9] Ward, J., \& Peppard, J., Strategic Planning for Information Systems. New York: John Wiley \& Sons, 2002.

[10] Tim Penyusun, Rencana Strategis Jurusan Ilmu Komputer FMIPA 2016-2020. Lampung: Jurusan Ilmu Komputer, 2015 